\title{
Hermenêutica filosófica e marxismo: sobre uma peculiar "ausência-presença"
}

\author{
Philosophical hermeneutics and marxism: on a \\ peculiar "absence-presence"
}

\section{Vitor Bartoletti Sartori ${ }^{\star}$}

\section{Resumo}

Neste artigo, busca-se trazer à tona pontos comuns na obra marxiana e na hermenêutica filosófica, tendo-se por central as categorias, já presentes em Hegel, da objetivação e do estranhamento. Tanto Marx quanto a tradição hermenêutica opõem-se ao legado hegeliano, no entanto, ao fazê-lo, a hermenêutica filosófica deixou de considerar com seriedade a tradição marxista, que, de um modo ou de outro, teve por central a relação entre espírito e natureza, bem como a questão da objetivação, temáticas que aparecem com destaque na hermenêutica filosófica. Desenvolve-se, assim, uma peculiar "ausência-presença" do pensamento marxiano, abordado por autores como Dilthey, Heidegger e Gadamer, na medida em que não foi visto de modo suficientemente cuidadoso. Ao passo que um importante marxista, György Lukács, tratou com cuidado de autores cujo posicionamento é oposto ao seu (Dilthey e Heidegger por exemplo), infelizmente, o mesmo não se deu (pelo menos de modo devido no que toca a Marx) com a hermenêutica filosófica, que poderia ganhar muito no debate/embate com o marxismo.

Palavras-chave: Hermenêutica. Hermenêutica filosófica. Marx. Hegel.

\section{Abstract}

In this article, we intend to bring certain common aspects of Marx'work and philosophical hermeneutics. This will be done having in mind the Hegelian notions of objectification and alienation. Marx and the hermeneutic tradition criticize Hegel; although when the hermeneutic tradition does it, it does not

* Professor do departamento do Direito do trabalho e introdução ao Direito da UFMG, bacharel em Direito pela USP, mestre em História social pela PUC SP e doutor em filosofia do Direito pela USP. São Paulo - SP - Brasil. E-mail: vitorbsartori@gmail.com 
take seriously enough the Marxist tradition, which, actually, deals with important themes such as the relation between spirit and nature and the matter of objectification, key aspects to the hermeneutic tradition. This tradition develops itself in a peculiar absense-presence to the Marxian thought, studied took in account by authors such as Dilthey, Heidegger, Gadamer and others in a very problematic way. Lukács, an important Marxist of the twentieth century, dealt with non-Marxist authors (as Dilthey and Heidegger, for instance); but, unfortunately, the hermeneutic tradition didn't take the same precautions with the Marxist thought and, this tradition could gain a lot with this debate, which could lead to interesting oppositions.

Keywords: Hermeneutics. Philosophical hermeneutics. Marx. Hegel.

\section{Introdução}

No presente artigo, busca-se trazer à tona a hipótese de que pode haver um debate/embate proveitoso entre a hermenêutica filosófica e os textos filosóficos marxianos, o que se daria uma vez que haveria certa "ausência-presença" de Marx em autores como Dilthey, Heidegger, Gadamer e Paul Ricoeur, centrais para a tradição hermenêutica. Tendo por objetivo demonstrar que esta "ausência-presença" se dá a partir de duas críticas distintas à tradição hegeliana (a crítica advinda da hermenêutica e a crítica marxiana), procura-se explicitar como isso aparece, especificamente, ao se ter em mente, de um lado, a relação que os distintos autores têm com a natureza e a efetividade (Wirklichkeit), e, por outro lado, em especial, a categoria do estranhamento (Entfremdung), bem como aquelas com as quais se relacionam desde Hegel - alienação (Entäusserung) e objetivação (Vergegenstandlichung), por exemplo tanto em Marx como na tradição da hermenêutica filosófica.

Ao tratar disso, será possível mostrar como justamente o tratamento marxiano ao estranhamento (Entfremdung) não é conhecido pelos autores aqui tratados em oposição ao autor de O capital, tendose, assim, certo tratamento de Marx por parte da hermenêutica filosófica que, com exceção de Heidegger, caracteriza-se pela redução de seu 
pensamento a uma forma de "sociologismo" ou de "naturalismo". Tendo em conta estes aspectos, a partir da análise dos textos marxianos e daqueles de autores como Dilthey, Heidegger e Gadamer (sem prejuízo de apontamentos sobre a obra de autores como Paul Ricoeur), procurase mostrar como se delineiam algumas questões centrais tanto para a hermenêutica filosófica quanto para Karl Marx.

Assim sendo, algumas questões centrais dizem respeito às duas distintas críticas ao pensamento hegeliano, sendo essencial compreender o modo como se constituem distintas formas de compreensão (a marxiana e da hermenêutica filosófica) a serem acordadas acerca da relação entre realidade efetiva (Wirklichkeit), atividade e natureza; relação esta que, em verdade, é problematizada, tanto por Marx quanto pela tradição hermenêutica, em uma espécie de diálogo crítico com a tradição hegeliana. A questão central a ser tratada no presente texto diz respeito, portanto, à maneira pela qual vem a ser decisivo o modo como o "acerto de contas" com Hegel influencia o desenvolvimento de duas tradições filosóficas importantes. Algo que emerge como decorrente disso diz respeito justamente à maneira pela qual, tendo em conta certas temáticas comuns (mencionadas nos parágrafos acima), pode ser frutífero um franco diálogo entre o marxismo (visto pela obra do próprio Marx, mas também pela obra de autores como György Lukács) e a tradição hermenêutica.

O percurso desse artigo tem por linha mestra justamente esse pano de fundo, tratado aqui ao se tornar claro que o marxismo pode trazer uma abordagem filosófica sofisticada e rigorosa e que, como tal, pode ser levada em conta pelo melhor da filosofia não marxista. Assim, abordaremos alguns dos fundamentos teóricos presentes no campo da hermenêutica filosófica, em especial aqueles tratados como uma espécie de antessala para a hermenêutica jurídica e que remetem, mesmo que de modo indireto, a uma tradição filosófica que, hoje, principalmente no campo da ciência jurídica, aparece eclipsada: aquela advinda da obra de Karl Marx. Não há aqui a pretensão de se resolver quaisquer querelas que possam advir do embate de Marx com os autores da hermenêutica filosófica, tendo este artigo um escopo bem mais modesto: explicitar, 
nos termos que se colocou acima, como a obra marxiana aparece como uma espécie de "ausência-presença" na tematização da interpretação.

A partir da explicitação de alguns temas comuns entre a tradição marxiana e aquela que resulta em uma abordagem hermenêutica (aqui são de grande relevo autores como Schleiermacher, Dilthey, Heidegger e Gadamer ${ }^{1}$ ), pretende-se mostrar que, ao mesmo tempo em que essa última compartilha com o marxismo determinadas temáticas, tem-se posicionamentos que, permeados por uma tensão específica com a dialética hegeliana, remetem a modos distintos e antagônicos de lidar com a natureza, a história (Gechichte) e a historicidade (Gechichlichkeit), temáticas que aparecem na teoria marxiana permeadas pela noção de atividade humana sensível (sinnlich menchliche Tätigkeit) e, na hermenêutica filosófica, têm em conta uma relação bastante distinta com a prática social, com o mundo circundante, com a compreensão (Verstehen) e com a tradição.

\section{Marxismo e hermenêutica? Ressalvas e apontamentos necessários}

Tendo-se mencionado tal questão, é válido destacar que, ao referir-se à obra de Marx, não se tem em conta esquemas conceituais ou algo como o "materialismo dialético", que seria "aplicado" nas relações sociais, dando ensejo ao "materialismo histórico". Tal apreço pelo pior do "método" pretensamente científico - este último sendo entendido de modo simplificador, como um esquema que precede a pesquisa e a apreensão da realidade propriamente ditas - em verdade, como mostraram autores como Lukács (2010) e Chasin (2009), é algo absolutamente estranho ao universo categorial marxiano.

Bom ressaltar desde já que, neste artigo, considera-se a hermenêutica romântica (SCHLEIERMACHER; DILTHEY) juntamente com Heidegger e Gadamer, sendo possível uma definição mais restrita da noção de hermenêutica filosófica: "a hermenêutica filosófica [...] é de uma data bastante recente. No sentido restrito e usual, ela designa a posição filosófica de HansGeorg Gadamer e, eventualmente, também a de Paul Ricoeur." (GRODIN, 1998, p. 24). Em alguns momentos também trata-se de aspectos que remetem diretamente à obra de Ricoeur. 
Assim, no século $X X$, pode-se dizer, houve algo que desvirtuou substancialmente a apreensão do modo pelo qual Marx procurou tratar da realidade efetiva (Wirklichkeit). O "marxismo" esteve marcado por um apelo tático (e taticista) decorrente da hegemonia stalinista². Deste modo, no stalinismo, tem-se uma inversão brutal da posição (Standpunkt) materialista (e ontológica ${ }^{3}$ ) de Marx, pois, como apontou Lukács (1986, p. 63) em sua maturidade ao referir-se ao stalinismo, "na práxis a atuação não é regulada pela mais profunda inteligência das coisas, ao contrário, essa mais profunda inteligência é construída em função da tática do agir". Em verdade, diante deste cenário, não foi incomum acreditar que grandes temas da filosofia clássica alemã, como a relação entre objetivação (Vergegenstandlichung), alienação (Entäusserung) e estranhamento (Entfremdung), não poderiam ser tratados de modo coerente com o corpus da filosofia marxiana, a qual poderia ser deixada de lado ao se remeter a estas questões, pungentes em autores que estão ligados a Heidegger, grande referência ao se tratar da hermenêutica.

Neste sentido, é preciso destacar que, tendo deixado de buscar a "profunda inteligência das coisas", o "marxismo", não raro, fora reduzido a uma espécie de exercício de sociologismo vulgar e, claro, não se procura aqui valorizar isso. Aponta-se somente que um embate importante entre a hermenêutica filosófica (conformada, sobretudo, depois de Heidegger e Gadamer), a hermenêutica jurídica (ligada a autores como Emilio Betti) e a posição marxiana (que Lukács tentou recuperar no final de seu vida) ${ }^{4}$ deixou de ser realizado com o cuidado necessário, e que, acredita-se, poderia ser proveitoso.

Vê-se como óbvio que não é possível simplesmente procurar realizar um diálogo que não ocorreu efetivamente. No entanto, não é

2 Diz o filósofo húngaro György Lukács (1972, p. 32), na época: “o marxismo, concebido acertadamente, [...] não existe mais.". E, neste sentido, ainda destaca: "o stalinismo é mais que uma interpretação errônea ou uma aplicação descuidada do marxismo; é uma negação do marxismo. Com stalinismo não há teóricos, só táticos."

3 Como aponta Lukács (2010, p. 71): "a crítica de Marx é uma crítica ontológica".

4 Cf. principalmente Lukács $(2010,2012,2013)$. 
possível que se deixe de notar que categorias explicitamente centrais para os Manuscritos econômico-filosóficos de Marx (mas também para os Grundrisse), como aquelas da objetivação (Vergegenstandlichung), da alienação (Entäusserung) e do estranhamento (Entfremdung), são também de grande relevo para os autores da tradição filosófica que enxergam com bons olhos uma abordagem hermenêutica.

Para que se ilustre a questão, primeiramente por via inversa e, depois, pela via convencional, pode-se mencionar, mesmo que rapidamente, que, no campo da hermenêutica jurídica "crítica", por exemplo, Óscar Correas (1995) sequer se remete a essas noções ao tentar aproximar a crítica marxista da ideologia à interpretação jurídica, sendo obrigado a trazer a linguística e a semiologia (em várias vertentes, nem sempre compatíveis entre si) como aliadas, ou seja, justamente na medida em que vem a desconsiderar aquilo que fora visto como central por outros autores e, antes deles, por Hegel (LUKÁCS, 1963), Correas desenvolve uma concepção que, quer queira, quer não queira, traz consigo certo germe de ecletismo.

Ainda para tratar de um autor que tem "um pé" fixado na hermenêutica jurídica, Betti (2007), por exemplo, tem por central a questão da objetivação (Vergegenstandlichung) ${ }^{5}$, mas, em verdade, deixa de problematizar o tema com o devido cuidado, e, neste sentido específico, sequer é coerente com a influência neo-hegeliana que traz ao campo da hermenêutica jurídica através da hermenêutica filosófica. Ainda se pode mencionar a posição que passa por Heidegger e Gadamer, mas que procura remeter para além dela: aquela corporificada de modo expressivo em, por exemplo, Ricoeur. Essa posição, por sua vez, problematiza a alienação (Entäusserung), porém, vem a deixar de lado um tratamento rigoroso do estranhamento (Entfremdung), central para Heidegger, pelo menos desde Ser e tempo. Com isso, procura

Betti (2007, p. XL) aponta que uma das tarefas da hermenêutica seria justamente buscar certa forma de autorreconhecimento em meio às objetivações (Vergegenständlichung) do espírito e, "tratando-se de objetivações do espírito, [...] a tarefa do sujeito consiste em voltar a conhecer, em reconhecer nessas objetivações o pensamento animador, em repensar a concepção ou reevocar a intuição que nelas se revela." 
Paul Ricoeur trazer à tona certo ganho interpretativo ao se enfocar no distanciamento (Verfremdung), buscando compreender a hermenêutica como um processo interpretativo oriundo da dialética entre explicar (Erklären) e compreender (Verstehen), aspectos intimamente relacionados às categorias tematizadas de modo cuidadoso no corpus da filosofia marxiana, pois aparecem com algum destaque.

Portanto, no campo da hermenêutica, quer queira, quer não queira, os temas mencionados no parágrafo acima são essenciais e, nessa medida, infelizmente, foram tratados sem referência cuidadosa a um importante filósofo como Marx, autor que, muito embora não possa ser considerado de modo algum um hermeneuta, passou por temas que permeiam a concepção de mundo hermenêutica (Weltanschauung). Dessa forma, poderia contribuir para problematizar determinadas abordagens desses autores, seja por certa proximidade temática, seja pela discordância quanto ao modo como a resolução das questões colocadas poderia ser radicalmente diferente do que o foi em Schleiermacher, Dilthey, Heidegger ou Gadamer.

Com isso, resta que a tematização marxiana não é destituída de cuidado filosófico, como muitos no campo da filosofia do Direito chegam a cogitar, sendo sua filosofia "digna de tal nome", porque trata de temas centrais à nata de uma das fortes tradições da filosofia do século $X X$ e da atualidade. Ao mesmo tempo, a fundamentação da posição (Standpunkt) ${ }^{6}$ do marxismo é ligada à práxis, pois consegue, também por causa dessa ligação (LUKÁCS, 2010), lidar com as grandes questões da filosofia, as quais aparecem aqui quando se busca trazer à tona a tradição da hermenêutica filosófica.

Assim sendo, é possível mesmo apontar que pode existir certo ponto cego no debate filosófico e jusfilosófico sobre a interpretação. Talvez se possa dizer que, ao mesmo tempo em que a hermenêutica filosófica, na esteira de Heidegger, procura ultrapassar uma abordagem formalista e imobilizadora (SARTORI, 2010, 2012), ela acaba negligenciando um

\footnotetext{
6 Para um tratamento cuidadoso da noção de Standpunkt, Cf. Lopes (2010).
} 
tratamento cuidadoso dispensado ao estranhamento (Entfremdung), tal como tematizado por Marx já nos Manuscritos econômico-filosóficos, e cuja importância decisiva nos rumos da sociedade atual foi destacada, sobretudo, por Lukács em sua Ontologia do ser social. Este ponto, porém, não pode ser tratado com cuidado aqui, merecendo somente breve menção.

Como aponta Tertulian (2009), isso ocorre quando o formalismo reificado remete justamente ao tratamento da reificação (Verdinglichung), impensável sem remissão ao estranhamento (Entfremdung $)^{7}$. Aqui não se pretende, é claro, resolver o modo pelo qual talvez exista certo ponto cego na hermenêutica filosófica, que tem como grandes expoentes, e nortes, Heidegger e Gadamer. Indicaremos somente a existência e importância da tematização deste "ponto cego", que se mostra de grande relevo na conformação mesma da hermenêutica filosófica, seja por ser abordado de modo apressado, seja por restar tomado como uma questão supostamente secundária.

O cenário que marca o tema de que se pretende tratar, em verdade, é pantanoso: mostra-se ao se considerar que certo modo de se relacionar com a filosofia hegeliana é essencial para a tradição da hermenêutica filosófica. Mas, ao mesmo tempo, uma grande crítica ao sistema hegeliano, a feita por Marx, que inclusive tematiza explicitamente categorias de grande importância para um Heidegger e um Gadamer, vem a ser deixada de lado em sua complexidade e valor. Trazer à superfície as posições de Marx e desses autores, assim, pode contribuir tanto para o desenvolvimento do marxismo quanto para o desenvolvimento de uma concepção que tenha apreço por autores contrários a Marx. Talvez seja mesmo possível ter como referência o velho Lukács nessa questão, o qual, em sua Ontologia do ser social, procurou tratar com o maior rigor possível os autores advindos de tradições filosóficas opostas

\footnotetext{
Isso não ocorre somente em Marx, diga-se de passagem. O tema aparece de modo pungente em Lukács, desde História e consciência de classe, e é essencial também para o tratamento do impessoal (das Man) no primeiro Heidegger, tratamento este que reverbera também no tratamento do autor sobre apatricidade (Heimatlosskeit) e sobre a técnica. (SARTORI, 2010, 2012; TERTULIAN, 2006, 2009)
} 
à sua, tendo por resultado o desenvolvimento de um corpus filosófico que procura provar (e, acredita-se, prova efetivamente) que o marxismo é uma grande filosofia, capaz de lidar com as temáticas tratadas pela filosofia do século XX. Acredita-se que, no "lado oposto" do espectro filosófico (aquele da hermenêutica filosófica), este procedimento possa ser igualmente proveitoso, dado que mesmo autores que procuraram levar a sério a filosofia de Marx, tais como Heidegger e Ricoeur, na melhor das hipóteses, mostraram uma compreensão parcial do autor.

\section{Hermenêutica e dialética: uma relação tensa e a "presença-ausência" de Marx}

Tendo esta temática em conta, parece importante destacar o modo pelo qual temas muito presentes na teoria marxiana (e não no famigerado "marxismo-leninismo") vêm à tona na tradição da hermenêutica filosófica de modo oposto ao como apareciam no autor de O capital, tendo-se não só uma contraposição entre fenomenologia e dialética (TERTULIAN, 2009), mas uma verdadeira contraposição entre hermenêutica e dialética ${ }^{8}$.

Além disso, como aponta Gadamer (2009, p.18), "Heidegger considerou até o final de sua vida a dialética como o risco corruptor propriamente dito do trabalho fenomenologicamente sólido." Isso ocorre também porque uma compreensão acerca da realidade efetiva (Wirklichkeit) como algo constituído em meio à atividade prática e social dos próprios homens, mesmo que não seja simplesmente deixada de lado, aparece em um plano, por assim dizer, secundário na tradição da hermenêutica filosófica. Ou seja, à medida que temas centrais na

Neste ponto vale apontar que, a nosso ver, muito embora a tentativa de Paul Ricoeur de buscar uma conciliação neste campo, mesmo que bastante instrutiva sobre diversos aspectos e interessante sobre outros, ao final, não teria como ser bem-sucedida, dado que, como pretendemos mostrar neste artigo, não seria possível valorizar noções como a de acontecimento (Ereignis) e ao mesmo tempo trazer o cuidado suficiente para o tratamento da dialética entre objetivação (Vergegenstandlichung), alienação (Entäusserung) e estranhamento (Entfremdung), central a uma concepção que valoriza a história como um campo efetivo da atividade humana. 
filosofia hegeliana, desenvolvidos de modo distinto em Marx, aparecem também como pungentes na abordagem hermenêutica, eles são tratados ou com certa indistinção entre alienação (Entäusserung) e estranhamento (Entfremdung) ${ }^{9}$ - o que, segundo autores como György Lukács, vem a tomar o estranhamento como uma espécie de "condição humana"10 -, ou com a não tematização cuidadosa do estranhamento (Entfremdung), visto que aspectos relacionados a ele são tidos como partes constitutivas do percurso e do processo hermenêutico mesmo, como ocorre na figura do distanciamento (Verfremdung) em Ricoeur.

O fato de Ricoeur (2008) (em especial em Hermenêutica e ideologias) procurar um diálogo com a crítica marxista às ideologias e com a psicanálise deixa claro, ao mesmo tempo, duas questões: o ponto cego advindo da não tematização rigorosa da objetivação (Vergegenstandlichung), da alienação e do estranhamento em Marx; e o fato de, mesmo sem esta tematização, o marxismo aparecer enquanto referência obrigatória àqueles que querem tratar com seriedade da filosofia. Neste sentido, remete-se novamente à importância de se tratar deste "ponto cego", mencionado acima, o que traz à tona a tematização da própria atividade humana a partir de certa "ausência-presença" de Marx na tematização hermenêutica.

Talvez possa mesmo ser essencial explicitar, simultaneamente, algumas similitudes temáticas e diferenças essenciais que se colocam entre Marx e a tradição hermenêutica. Com isso, pode-se mostrar como que aquilo que é visto enquanto eivado por determinações sociais por parte de Marx, não raro, em meio à conformação da hermenêutica

9 Ao que tudo indica, inclusive, nenhum autor ligado a esta tradição sequer buscou tratar separadamente de tais termos que, em Hegel, aparecem também, sempre, de modo conjunto. (ABBIERO, 2015).

10 O marxista húngaro é bastante duro com tal questão, dado que, segundo ele, o estranhamento seria um fenômeno intrinsecamente social no sentido de que seria real e efetivo somente em sociedades marcadas pelo antagonismo classista e, segundo Lukács, passível de supressão (Aufhebung). Veja-se o autor: "para a crítica filosófico-burguesa da civilização - basta pensar em Heidegger -, era muito óbvio sublimar a crítica social numa crítica puramente filosófica, fazer da alienação, social em sua essência, uma conditione humaine eterna, para utilizar o termo que surgirá só mais tarde." (LUKÁCS, 2003, p. 26) 
filosófica de talhe heideggeriano e gadameriano, vem a ser tomado como algo que um marxista como Lukács (1947), por exemplo, não pode deixar de apontar como dotado de uma objetividade fantasmagórica, criticada pelo autor de $\mathrm{O}$ capital e, posteriormente, enquanto algo de pseudo-concreto (KOSIK, 1995) que passa "ao lado da estrutura objetiva da época." (LUKÁCS, 1947; SARTORI, 2010, 2012). Aqui, contudo, não se pode avançar no desenvolvimento de tais temas.

É preciso, entretanto, deixar claro que não se trata de buscar explicitar o ponto cego mencionado para tornar conciliável aquilo que não é. Neste sentido, vale destacar que, à medida que se aborda tais temas - caso se parta de autores como Marx e Lukács, autores praticamente ausentes dos debates jusfilosóficos contemporâneos -, torna-se possível dizer que, na tradição hermenêutica, não deixa de haver certa naturalização dos mesmos, os quais, diante de determinada posição prática - aquela do jurista intérprete no caso da hermenêutica jurídica, e da abordagem fenomenológica e hermenêutica no caso da hermenêutica filosófica -, vêm a deixar de lado justamente questões que seriam decisivas no que diz respeito à crítica real e efetiva da sociedade civil-burguesa (bürgerliche Gesellschaft), tematizada explicitamente por Marx e pela tradição marxista.

Nesse sentido, uma crítica às ideologias, como a que pretende Ricoeur, vem a deixar de lado fundamentos importantíssimos da crítica marxiana, tendo-se certa hermenêutica que, não obstante interessante, não poderia efetivamente, diante de tal "ponto cego", conciliar dialética e hermenêutica. Ricoeur se remete a Hegel e à supressunção (Aufhebung) hegeliana em sua teoria acerca da interpretação (principalmente como desenvolvida em Hermenêutica e ideologias), mas, ao buscar uma apropriação crítica dele - mediante o silêncio - vem a tomar justamente o acerto de contas de Marx com Hegel como algo que não seria proveitoso para questões filosóficas centrais. Assim, pode-se notar certa ausênciapresença de Marx. 


\section{O papel da crítica a Hegel}

Para que possamos começar a tratar do tema traçado de modo mais concreto, é importante dizer que, por vezes, Hegel - autor tematizado por Dilthey, Heidegger e Gadamer (de modo oposto ao que traz Marx) - parece mesmo tomar a efetividade (Wirklichkeit) como sinônimo de manifestação (Äusserung), alienação (Entäusserung), estranhamento (Entfremdung) ${ }^{11}$ do espírito (Geist), mencionando haver, em meio à cultura (Bildung), "o mundo da efetividade ou o da alienação (Entfremdung) do espírito" (HEGEL, 1992, p. 35).

Assim sendo, caso se tome uma posição materialista, como a do autor de $O$ capital, parece haver certa inversão no pensador da Fenomenologia no espírito: nele, é o espírito que parece dar ensejo à realidade efetiva (Wirklichkeit) e não essa última, que estabelece as bases reais sem as quais o espírito não tem sustentação real alguma. Tal inversão seria pungente ao se considerar que, nas palavras de Karl Marx, em verdade, "momento filosófico não é a lógica da coisa (Sache), mas a coisa da lógica" (MARX, 2005, p. 39) (Nicht die Logik der Sache, sondern die Sache der Logik ist das philosophische Moment) ${ }^{12}$.

Hegel, dessa maneira, parece fazer a filosofia, com sua lógica inerente, dar sustentação à realidade, e não o oposto, como quer o autor da Crítica à filosofia do Direito de Hegel. Trata-se, segundo Marx, de uma peculiar inversão entre sujeito e predicado, inversão esta que é tematizada pelo autor socialista durante toda sua trajetória e que aparece de modo marcante em passagens famosas como aquela acerca do

11 Aqui, adotamos a tradução indicada por Ronaldo Vielmi Fortes na tradução dos Prolegômenos para uma ontologia do ser social, de György Lukács. Tendo em conta a natureza controversa da tradução das expressões, sempre que julgarmos necessário, colocaremos o original em alemão ao lado. Vale notar também que tende a haver certo uso conjunto destas expressões no autor da Fenomenologia do espírito e, somente neste sentido, tomamos a liberdade de utilizá-los quase que como sinônimos neste momento. Para os distintos usos que Hegel faz dos termos, vale conferir o ótimo texto de Marcella D'Abbiero (2015) sobre A "alienação" em Hegel: usos e significados de Entäusserung,Entfremdung, Veräusserung.

12 Neste sentido, "em outras palavras, a lógica coexiste com seus objetos, sendo que as conexões do real são conexões lógicas que o sistema der Hegel pretende compreender." (RANIERI, 2011, p. 40). 
"caráter fetichista da mercadoria" (SARTORI, 2014). Em grande parte, a "inversão" materialista de Marx teria como objetivo desfazer o traçado hegeliano sobre esse aspecto, e, é preciso ter isto claro, não se voltar a qualquer sociologismo vulgar.

Neste ponto, talvez seja possível concordar com Jesus Ranieri quando diz, com base na leitura marxiana, mas, principalmente, lukacsiana sobre Hegel, e, em especial, sobre o jovem Hegel (sendo um espaço bastante profícuo a obra de "juventude" hegeliana, dado que é desta tematização que partem também autores como Habermas e Honeth), que haveria nele, em verdade, "a intenção de juntar elementos a um só tempo lógicos e ontológicos em uma única Lógica que se pretende gnosiológica e detentora de todos os passos da gênese do movimento do ser social." (RANIERI, 2011, p. 40). Dilthey (1950, p. 191), por seu turno, aponta que a Fenomenologia do espírito "é a primeira tentativa para estabelecer uma filosofia da história combinando o idealismo e a história", ou seja, tem-se, como pano de fundo comum à concepção hermenêutica, certo tom bastante crítico quanto à centralidade da lógica e do idealismo racionalizante em Hegel.

Certamente, no campo do materialismo marxiano, a questão não se apresenta de modo tão direto como pode parecer que se sugere, até mesmo porque o próprio Marx nunca considerou Hegel como um "cachorro morto", mas sim como alguém a quem, inclusive, até certo ponto, poderia se filiar no que toca ao ímpeto dialético ${ }^{13}$. Marx, portanto, valoriza explicitamente a tonalidade dialética da filosofia hegeliana, não

13 Veja-se Marx: "critiquei o lado mistificador da dialética hegeliana há quase trinta anos, quando ela ainda estava na moda. Mas quando eu elaborava o primeiro volume de $\mathrm{O}$ capital, os enfadonhos, presunçosos e medíocres epígonos que hoje pontificam na Alemanha culta acharam-se no direito de tratar Hegel como o bom Moses Mendelssohn tratava Espinosa na época de Lessing: como um "cachorro morto". Por essa razão, declarei-me publicamente como discípulo daquele grande pensador e, no capítulo sobre a teoria do valor, cheguei até a coquetear aqui e ali com seus modos peculiares de expressão. A mistificação que a dialética sofre nas mãos de Hegel não impede em absoluto que ele tenha sido o primeiro a expor, de modo amplo e consciente, suas formas gerais de movimento." (MARX, 2013, p. 129). No que toca a distinção entre as posições de Marx e de Hegel, vale conferir o texto De Hegel a Marx: da inflexão ontológica à antítese direta. (SARTORI, 2014). 
vendo esta tonalidade como a fonte do caráter problemático da teoria do autor de Fenomenologia do espírito. Segundo o autor de O capital, a dialética hegeliana tomaria rumos idealistas na medida em que "a suprassunção (Aufhebung) da alienação (Entfremdung) ${ }^{14}$ é identificada com a suprassunção da objetividade (Gegenstandlichkeit)." (MARX; ENGELS, 2007, p. 541). Assim sendo, Marx conforma-se enquanto um materialista também na medida em que se contrapõe ao modo pelo qual a categoria da "suprassunção" é operada na filosofia hegeliana, tendose um modo mais concreto e fortemente eivado pela tonalidade negativa da "supressão" (Aufhebung) no pensamento do autor (SARTORI, 2014).

As críticas de Marx ao pensamento de Hegel têm por centro organizador, em diversos aspectos, justamente a relação entre objetivação (Vergegenstandlichung), alienação (Entäusserung) e estranhamento (Entfremdung), pois, sendo possível dizer que a tradição hermenêutica que vai de Schleiermacher até Gadamer, e reverbera até hoje, talvez somente possa lidar com sua própria problemática de modo proveitoso ao ter em conta com cuidado também o tratamento marxiano das questões apontadas, se uma das questões que se impõe à hermenêutica é a apropriação daquilo que se apresenta enquanto estranhado, pode ser bastante interessante um embate decisivo por parte dessa tradição com aquilo que disse Marx sobre o estranhamento ${ }^{15}$.

\footnotetext{
14 A partir deste ponto de nosso texto, para que mantivéssemos as traduções dos textos que consultamos, fomos obrigados a tolerar diferentes traduções para os termos que aqui tratamos em nosso texto.

15 Vale apontar que, tendo em conta a alienação (Entäusserung), Ricoeur, mesmo que busque explicitamente certa retomada da dialética, e mesmo da tradição hegeliana, não traz a questão do estranhamento (Entfremdung) à tona com cuidado, relacionando de modo, talvez abrupto, a alienação com o distanciamento (Verfremdung) ao tratar da questão da apropriação, dando mesmo ensejo a certa reconciliação com a temática do estranhamento (vista de modo bastante ácido em Heidegger com referência ao impessoal (Das man)): 'também o conceito de 'apropriação' exige uma crítica interna na medida em que permanece dirigido contra a Verfremdung. Com efeito, a metamorfose do ego, que acabamos de falar, implica um momento de distanciamento até na relação de si a si. A compreensão torna-se, então, tanto desapropriação quanto apropriação. Uma crítica das ilusões do sujeito, à maneira marxista e freudiana, não só pode, mas deve ser incorporada à compreensão de si." (RICOEUR, 2008, p. 69) No lugar do estranhamento, em Ricoeur, aparece a valorização do distanciamento.
} 
Isso ocorre também ao passo que o autor de $\mathrm{O}$ capital critica em Hegel justamente certa solução ilusória que, ao procurar lidar com o estranhamento, tiraria de campo a realidade efetiva (Wirklichkeit) mesma, rumando a uma tematização de um ser (Wesen) não objetivo, sendo que, para Marx, "um ser não objetivo é um não-ser." (MARX, 2004, p. 127) (“Ein ungegenständliches Wesen ist ein Unwesen”). Neste sentido, também urge um debate claro sobre a forma pela qual a tradição hermenêutica enxerga a questão do Ser (Sein) e aquela pela qual Marx, também em oposição a Hegel (SARTORI, 2014), trata da questão. ${ }^{16}$

\section{Duas críticas a Hegel e ao hegelianismo e a "ausência- presença" de Marx na tradição hermenêutica}

A equação entre o idealismo especulativo e uma relação tensa com a temática do estranhamento (Entfremdung) se daria na medida em que a solução hegeliana estaria em um contrassenso: seguindo os passos de Marx, aponta Lukács (2003, p. 26), que "como para Hegel o objeto (Gegenstand), [e] a coisa (Sache), só existem como exteriorização (Entäusserung) do sujeito, seria o fim da realidade objetiva, ou seja, da realidade em geral." $E$, nesse sentido preciso, a abordagem fenomenológica - já presente no autor da Fenomenologia do espírito - dá um passo adiante. Nessa mesma medida, tem-se um ponto em que a crítica marxiana é bastante ferrenha: a suprassunção (Aufhebung) hegeliana operaria logicamente somente visto que desconsidera, ao fim, as próprias determinações objetivas da realidade efetiva (Wirklichkeit). Tendo em conta o tratamento do Direito e a posição (Standpunkt) segundo a qual "um ser não objetivo é um não-ser", aponta Marx que, no autor alemão, ao final, tudo se passa na medida em que, filosoficamente, "o verdadeiro interesse não é a filosofia do direito, mas a lógica" (MARX, 2005, p. 38). Pode-se mesmo dizer que tal abordagem, seria compatível com uma definição de fenomenologia que não deixaria de incomodar muito qualquer autor materialista: aquela traçada, já no século XX, por

16 A questão é tematizada sobretudo por Lukács (2010, 2012, 2013). 
Lévinas: "a fenomenologia é uma destruição da representação e do objeto teorético." (LÉVINAS, 1998, p. 139). Para resolver uma questão que se apresenta como dificultosa no campo da filosofia, Hegel, tal qual a abordagem fenomenológica que viria a fazer carreira na tradição da hermenêutica filosófica, procura ultrapassar a própria objetividade (Gegenstandlichkeit) enquanto um objeto inerte (Objekt), com o custo de remeter para além da objetividade mesma, no caso, em meio à cultura (Bildung).

Porém, não se pode ser unilateral. Em Hegel, ao mesmo tempo, certamente, a questão se apresenta na medida em que não seria possível, de modo algum, hipostasiar a esfera, seja da "cultura" (Bildung), seja natural, que aparecera ao autor enquanto "estranhamento (Entfremdung) do espírito". Para Hegel, é "mediante a cultura que o indivíduo tem aqui vigência (Gelten) e efetividade (Wirklichkeit)" (HEGEL, 1992, p. 39) somente na medida em que se tem uma situação em que extrusão (Entäusserung) e alienação (Entfremdung) ${ }^{17}$ aparecem como inseparáveis na conformação da individualidade como tal.

A verdadeira natureza originária (ürsprungliche) do indivíduo, e [sua] substância (Substanz), é o espírito da alienação do ser natural (der Geist der Entfremdung des natürlichen Seins). Essa extrusão (Entäusserung) é, por isso, tanto o fim, como o ser-aí (Dasein) do indivíduo; é, ao mesmo tempo, o meio ou a passagem, seja da substância pensada para a efetividade (Wirklichkeit), como inversamente da individualidade determinada para a essencialidade (Wesentlichkeit). (HEGEL, 1992, p. 39).

Neste sentido específico, mesmo que a realidade efetiva (Wirklichkeit) possa aparecer, por assim dizer, como algo também de "espiritual", somente com o idealismo especulativo de Hegel - conformado na medida em que "a idealidade não é algo que haja fora e ao lado da realidade, mas o conceito de idealidade consiste

17 Utiliza-se aqui a tradução consagrada em Hegel, no Brasil, nesta passagem, pois a dicção que se utiliza aqui, neste ponto específico, faz referência justamente à posição hegeliana. 
expressamente em ser a verdade da realidade, isto é, que a realidade posta como é em si, mostra-se ela mesma como idealidade" (HEGEL, 2005 , p. 194) -, vem a unidade entre "mundo do espírito" e natureza. Unidade que, de modo diametralmente oposto, vai ser o alvo tanto de Dilthey quanto de Marx, autores das tradições filosóficas que aqui se tematiza. É importante notar, pois, que, seja na postura hermenêutica e fenomenológica que resultam em Heidegger e em Gadamer (e faz carreira ainda hoje), seja na postura ontológica de Marx e de Lukács (SARTORI, 2014), passa-se por um acerto de contas com temáticas importantes da filosofia hegeliana.

É bom apontar que, justamente da tematização das categorias da alienação (Entäusserung) e do estranhamento (Entfremdung), é possível buscar compreender os distintos modos pelos quais importantes autores, como Dilthey e Marx (mas também Heidegger e Gadamer) dão direcionamentos específicos para suas teorizações. Aqui, neste breve espaço, não podemos tratar da questão com todo o cuidado que ela mereceria.

No entanto, para os fins do presente texto, vale mencionar que a problemática acerca da relação entre o ser natural e o espiritual (em Marx, social) conforma-se na medida em que Dilthey, com sua distinção entre ciências do espírito (Geistwissenschaft) e ciências da natureza (Naturwissenschaft) - relacionada à distinção entre compreensão (Verstehen) e explicação (Erklären) - busca traçar uma cisão, que supõe certo estranhamento (Entfremdung) inelutável entre o entendimento da esfera do ser natural e do ser social. ${ }^{18}$ Marx, por seu turno - tendo em conta o afastamento das barreiras naturais, correlato justamente à crescente interação e inseparabilidade entre ser social e ser natural (LUKÁCS, 2010), e, assim, à possibilidade do homem, por meio da sociedade, dominar as potências naturais anteriormente conformadas

18 Tal estranhamento (Entfremdung) se dá, inclusive, na medida em que, como apontou Ricoeur (2009, p. 104): "a dicotomia entre compreensão e explicação na hermenêutica romântica é simultaneamente epistemológica e ontológica. Opõe duas metodologias e duas esferas da realidade: a natureza e o espírito. 
de modo estranho ${ }^{19}$ - vem a enxergar como inaceitável a unidade especulativa que chega a conceber a natureza somente na medida em que essa é o estranhamento (Entfremdung) do espírito no espaço e no tempo. ${ }^{20}$

Assim, tanto Dilthey quanto Marx, tratam de criticar o modo pelo qual se conforma a unidade entre natureza e espírito em Hegel. No entanto, podemos dizer que, ao passo que o primeiro a critica por ser, por assim dizer, "dialética em demasia"21 - tratar-se-ia da expressão da irracionalidade por meio da razão, o que levaria à dissolução da plenitude da vida (Leben) na lógica e na abstração, sendo essa somente possível em meio à explicação (Erklären), e não à atitude efetivamente compreensiva ${ }^{22}$-, o segundo, até certo ponto, critica-a por não sê-lo insuficientemente dialética. ${ }^{23}$

19 Aponta Lukács (1966, p.559) que "se bem que o trabalho fez o homem aquele que domina - durante muito tempo de modo problemático e potencial - as forças da natureza, por outro lado, o instrumento que o mesmo produziu sem saber nem querer, a sociedade, submeteu o homem mesmo a seu domínio. Somente quando realizado o socialismo, se supera (aufheben) essa segunda dominação e se abre uma equilibrada e sã relação de sujeito e objeto entre os mundos exterior e interior do homem."

20 Como aponta Lukács (1966, p. 314): "o afastamento das barreiras naturais [...] não significa só uma ampliação qualitativa da parte da natureza que controlada pela sociedade, mas também uma intensificação e complexificação das relações do homem com ela tomada em como totalidade, ou seja, também com partes que seguem estando fora do âmbito do controle humano. O processo de afastamento das barreiras naturais aporta, portanto, simultaneamente uma ampliação, um aprofundamento, um afinamento, etc., das relações do homem com a natureza, a respeito de todas suas manifestações vitais, ou o fazem pelo menos tendencialmente."

21 Veja-se como que a questão se delinearia, no que toca a distinção entre natureza e espírito, na época do autor: "a nova época da filosofia, na qual vivemos, caracteriza-se pela nova função que esta possui dentro da sociedade. Quando aparece, todavia, algum sistema doutrinal que abrange a natureza e o espírito, não lhe é possível influir na configuração da própria vida." (DILTHEY, 1950, p. 208). Justamente esta abrangência, criticada por Dilthey, está presente, de modo distinto, em Hegel e em Marx.

22 Ao tratar do modo de lidar com a história da filosofia de sua época, Dilthey a elogia justamente na medida em que se oporia a Hegel e ao caráter "abstrato" e "dialético" da teoria do autor da Fenomenologia do espírito. Segundo Dilthey (1950, p. 9) : "em oposição à atitude de Hegel, não se explica o desenvolvimento da filosofia em virtude das relações que mantém entre si os conceitos no pensamento abstrato, mas sim, em vista das modificações que se realizam no homem segundo a vida e realidade plenas."

23 É possível relacionar essas duas críticas ao autor da Fenomenologia do espírito com certa contradição entre "sistema" e "método dialético". Tal é a tese de Engels acerca da peculiaridade do corpus filosófico hegeliano: "com efeito, sua filosofia padecia ainda de uma grande contradição interna incurável, pois que, se, por um lado, considerava como suposto essencial da concepção histórica, segundo a qual a história humana é um processo de desenvolvimento que não pode, por sua própria natureza, encontrar solução intelectual no descobrimento disso que se chama verdades absolutas, por outro, se nos apresenta precisamente como resumo e compêndio de uma dessas verdades absolutas. Um sistema universal e compacto, definitivamente plasmado, no qual se pretende enquadrar a ciência da natureza e da história, é incompatível com as leis da dialética." (ENGELS, 1990, p. 22-23) A posição de Engels esclarece a existência da tensão que tratamos; no entanto, claro, somente enuncia tal questão, sem poder resolvê-la de modo satisfatório, até mesmo devido ao modo pelo qual a relação entre as ciências naturais e a emergência das ciências sociais se colocava em sua época. (LUKÁCS, 2010). Por parte de Dilthey, isso se dá na medida em que o "sistema" mesmo estaria se contrapondo à vida (Leben) na Alemanha de sua época: "cresce continuamente a tendência para uma filosofia liberta de sistemas, que busca compreender e valorizar a vida por si mesma." (DILTHEY, 1950). 
O primeiro traça o aspecto relativo e impossível de ser apreendido "objetivamente" em suas reais e efetivas determinações dos assuntos humanos, a "plenitude da vida" - advindos das objetivações (Vergegenständlichung) do espírito. O segundo, por seu turno, volta-se justamente à atividade social como critério de verdade, tendo-se a noção de atividade humana sensível (sinnlich menchliche Tätigkeit) por centro organizador da dialética entre objetivação (Vergegenstandlichung), alienação (Entäusserung) e estranhamento (Entfremdung), em que não aparecem contrapostas a vida (Leben) e a razão (Vernunft) em meio à exteriorização da vida (Lebensäusserung), como tratadas nos Manuscritos econômico-filosóficos.

Dito de maneira mais clara, a tradição que permeia Dilthey tem por trás de si, em meio à tematização teórica da vivência e da historicidade (Gechichlichkeit), a questão epistemológica do "como se pode conhecer" (que remete a Kant) já em meio à vida ${ }^{24}$. Já a tradição marxiana é explicita no sentido de "a questão de saber se ao pensamento humano caba alguma verdade objetiva não é uma questão de teoria, mas uma questão prática." (MARX; ENGELS, 2007, p. 537). Nesse sentido específico, para o autor da Ideologia alemã, "disputa acerca da realidade ou não realidade de um pensamento que se isola da prática é uma questão puramente escolástica." (MARX; ENGELS, 2007, p. 537) (Der Streit über die Wirklichkeit oder Nichtwirklichkeit des Denkens - das von der Praxis isoliert ist - ist eine rein scholastische Frage). Portanto, enquanto Dilthey procura separar aquilo que Hegel teria juntado de modo um tanto quanto abrupto (natureza e espírito), Marx procura apreender a unidade real e efetiva, que traz consigo não o télos da ideia supostamente efetiva, mas a complexidade mesma da realidade efetiva (Wirklichkeit) em suas determinações objetivas e históricas, que trazem

24 Veja-se como simultaneamente Dilthey (1950, p. 2010) procura resgatar a questão epistemológica e remeter à vida (Leben) deixando clara sua admiração pela filosofia de Schleiermacher: "ali aonde antes tínhamos a metafísica, a partir de Schleiermacher, achamo-nos com o problema das condições que, como pressupostos de um proceder racional, estão na base da atuação dos homens na sociedade." 
consigo, segundo Marx, ao mesmo tempo, a heterogeneidade entre o ser natural e o ser social, bem como a indissociabilidade dos mesmos. (LUKÁCS, 1966)

Em Marx, trata-se justamente de uma articulada e cuidadosamente apreendida "identidade da identidade e da não identidade" (LUKÁCS, 2010). Tão somente se poderia falar de vida (Leben) tendo em conta a práxis social em sua conformação verdadeira enquanto atividade humana sensível (sinnlich menchliche Tätigkeit). Sem levar em conta a complexidade articulada e diferenciada desta, para que usemos a dicção de Hegel em relação a Schelling, ter-se-ia um "claro-escuro em que todos os gatos são pardos".

Essa discussão é importante para o assunto que aqui se trata na medida em que denota um modo distinto de lidar com o estranhamento (Entfremdung), relacionado a um modo igualmente diferenciado de tratar das objetivações (Vergegenständlichung), sendo esta temática relacionada intimamente com maneiras distintas de lidar com a realidade efetiva (Wirklichkeit) mesma, seja enfocando o particularismo de cada compreensão (Verstehen) imiscuída na experiência vivida, seja procurando uma análise rigorosa da atividade humana sensível (sinnlich menchliche Tätigkeit).

No que se remete também à questão da totalidade, diante daquilo que Marx e Dilthey acreditaram ser uma união abrupta entre aspectos diferentes, o autor de $\mathrm{O}$ capital procurou tratar da unidade e da diferença como determinações reflexivas (Reflexionsbestimmungen), que remetem a um todo unitário, ao passo que Dilthey preconizou justamente a necessidade de uma cisão no modo pelo qual se compreende a realidade efetiva, pois "as dimensões alcançadas pelo saber tornam impossível o seu domínio por uma única mente e o enorme material necessário para as fundamentações quebra a conexão sistemática" (DILTHEY, 1950, p. 209), tendo-se como distintas a explicação (Erklären) e a compreensão (Verstehen), e sendo a última, é bom destacar, a fazer carreira na tradição hermenêutica que remete tanto a Heidegger quanto ao autor 
de Verdade e método. ${ }^{25}$ Essas são, faz-se necessário mencionar, referências obrigatórias para o desenvolvimento real da hermenêutica, e da tematização que aqui se procura apontar como certa ausênciapresença de Marx, também nesse sentido específico.

\section{A questão do estranhamento e as tentativas de superação do hegelianismo: atividade humana sensível, ontologia e fenomenologia}

Caso se tenha em conta a teoria marxiana, há de se admitir, com Dilthey, que a realidade efetiva (Wirklichkeit) certamente traz consigo formas de objetivação (Vergegenstadlichung) humanas. Isso se dá até mesmo porque um dos grandes erros das posições materialistas do passado teria sido, segundo Marx, "que o objeto (Gegenstand), a realidade (Wirklichkeit), o sensível (Sinnlichkeit) só é apreendido sob a forma do objeto (objekts) ou da contemplação (Anschauung), mas não atividade humana sensível (sinnlich menchliche Tätigkeit), como prática (Praxis); não subjetivamente." (MARX; ENGELS, 2007, p. 533). Esquivando-se de conceber a realidade efetiva somente enquanto intuição (Anschauung) ou objeto inerte (Objekt), Marx enfoca justamente que a objetividade (Gegenstandlichkeit) mesma traz consigo em seu processo constitutivo a dialética entre a atividade humana e as condições históricas, que têm a natureza como base e que remetem à relação entre objetivação, alienação (Entäusserung) e estranhamento (Entfremdung). A questão da práxis se coloca em Marx tendo em conta este pano de fundo.

Assim, o modo pelo qual o autor de O capital se afasta do idealismo especulativo de Hegel não traz tanto uma volta a qualquer empiria de um objeto inerte (Objekt), mas o enfoque na atividade humana sensível (sinnlich menchliche Tätigkeit), em que não há qualquer barreira

\footnotetext{
25 Segundo Ricoeur (2009, p. 105), isso se daria, inclusive, de modo unilateral, sendo preciso sempre destacar que "a interpretação não deve ser uma província da compreensão."
} 
intransponível entre a sensibilidade, a compreensão (Verstehen) e a razão (Vernunft), sendo possível e necessário relacionar a compreensão de um sujeito particular com a história (Gechichte), considerada, inclusive, enquanto um processo unitário.

Dessa forma, a "vida em sua plenitude", longe de aparecer como algo oposto às amarras da razão (Vernunft), mostra-se, em Marx, como algo marcado por relações que só poderiam ser compreendidas, de modo mediado, tendo-se em conta a práxis, em que sensibilidade, compreensão (Verstehen) e razão apareceriam, por assim dizer, "em ato".

Se em Dilthey, e depois em Heidegger e Gadamer, se desenvolve uma hermenêutica histórica que procura situar a relatividade da compreensão (Verstehen) dos homens em meio ao acontecer historial, em Marx, tem-se a compreensão relacionada não tanto à historicidade (Geschichtlichkeit), expressão essa que vai ser retomada com força por autores como Heidegger e Gadamer ${ }^{26}$, mas à história (Geschichte) - que está relacionado à dialética entre objetivação (Vergegenstandlichung), alienação (Entäusserung) e estranhamento (Entfremdung) - e que remete à tessitura complexa da práxis. Esta última, por seu turno, compreendida em sua totalidade, também é bastante importante na medida em que, em Marx, não se compreenderia de modo algum a "atividade humana sensível" (sinnlich menchliche Tätigkeit) com uma referência que fosse muito menos "prática" que considerada de forma essencial "subjetivamente", para que se possa remeter à dicção das Teses sobre Feuerbach.

Tendo essas questões em mente, diz Lukács, que talvez seja o mais importante marxista do século $X X$, que a postura fenomenológica, no limite, constituiria uma fuga frente à modernidade, a qual teria sido

26 Segundo Gadamer (2009, p.343), as noções utilizadas por Heidegger "buscam destacar a historicidade do ser-aí (Dasein) e não as estruturas fundamentais da história de seu conhecimento". Neste sentido específico, é clara certa ruptura tanto de Heidegger quanto de Gadamer em relação à tematização hegeliana da história, que considera esta última como um processo objetivo apreensível em sua efetividade mesma. 
elevada a um patamar de glória pela filosofia hegeliana com recurso ao Estado e ao espírito absoluto, sendo preciso, em Heidegger, algo que se opusesse à suprassunção (Aufhebung) hegeliana. O autor de Ser e tempo diz explicitamente: "o passo de volta (Schritt zurück), como regreso representa o movimento contrário do passo para diante, como progresso, de Hegel" (HEIDEGGER, 2006, p. 59). Para que se remeta ao assunto de que aqui se trata de modo mais direto, caso se tenha em conta uma posição materialista, ter-se-iam duas opções: primeiramente, como em Dilthey, Heidegger e Gadamer, tem-se o recurso à fenomenologia que remeteria à compreensão (Verstehen) originária (ürprunglich) ${ }^{27}$ do Ser (Sein) (ou da vida (Leben)) e, assim, procuraria algo distinto da realidade efetiva (Wirklichkeit) (e, vale lembrar que, para Marx, sempre a história é objetiva, dado que "um ser não objetivo é um não-ser"), tendose a abertura para uma crítica ácida por parte do marxismo, aquela crítica segundo a qual "a objetividade (Gegenständlichkeit) obtida desta maneira deve permanecer prisioneira daquilo subjetivamente vácuo, do vácuo subjetivo e a reflexão deve passar necessariamente ao lado da estrutura objetiva da época." (LUKÁCS, 1949, p. 37-38)28.

Neste sentido, seria retomado, mesmo que sem referência direta à filosofia hegeliana e à dialética entre objetivação (Vergegenstandlichung), alienação (Entäusserung) e estranhamento (Entfremdung), e sem referência à práxis real e efetiva, o "pior" da filosofia hegeliana. Utilizandose a dicção anteriormente mencionada por Lévinas, "a fenomenologia é uma destruição da representação e do objeto teorético." Ter-se-ia uma posição que oscilaria entre uma forma de pseudo-concretude (KOSIK,

27 Como aponta Heidegger (2010, p.35): "originário (ursprünglich) significa aqui aquilo a partir de onde e através do que algo é o que ele é e como ele é. A isto o que algo é, como ele é chamamos de essência. O originário de algo é o proveniente de sua essência."

28 O passo-de-volta (Schritt zurück) heideggeriano tem consigo o retorno à tematização présocrática, inclusive. Isso se daria na medida em que a familiaridade do cotidiano traria consigo o "impessoal" (Das Man) em que imperaria certo estranhamento (Entfremdung) sendo necessário, também neste sentido, um passo-de-volta frente à conformação cotidiana da sociedade moderna. Heidegger, assim, busca retomar o espanto grego tendo-se que, para o autor, "o espantar-se é o retroceder desde o corrente e familiar à abertura (Erschlossenheit) à influência do que se oculta [...]. Mas o mais corrente e, por isso, mais desconhecido, é o abandono do ser (Sein). O espantarse faz o homem retroceder frente a isto". (HEIDEGGER, 2006b, p. 30) 
1995) e a fenomenologia concebida de modo idealista, ou seja, uma forma de transcendência da própria objetividade (Gegenstandlichkeit), deixando-se a efetividade (Wirklichkeit) intocada.

A opção marxiana, nesse ponto, seria diametralmente oposta: seria preciso voltar-se à complexidade mesma da "atividade humana sensível" (sinnlich menchliche Tätigkeit) de tal feita que o ponto de partida primordial para tratar da historicidade (Gechichlichkeit) e da tradição ${ }^{29}$ (temas muito caros à hermenêutica filosófica), seria aquele segundo o qual "os homens fazem a sua própria história, mas não a fazem segundo a sua livre vontade; não a fazem sob circunstâncias de sua escolha e sim sob aquelas com que se defrontam diretamente, legadas e transmitidas pelo passado." (MARX, 1997, p. 21). Em MarX, na esteira de Hegel, mas também rompendo com o autor alemão, a historicidade mesma é subordinada à conformação objetiva da história (Gechichte), que tem consigo a mencionada dialética entre objetivação (Vergegenstandlichung), alienação (Entäusserung) e estranhamento (Entfremdung), impensável fora da atividade humana sensível.

A primeira questão que se percebe, pois, é que posições centrais à tradição hermenêutica, como aquelas ligadas à separação entre ciências do espírito e naturais, bem como ligadas à relação entre explicação (Erklären) e compreensão (Verstehen), permeiam também modos distintos de lidar com a teoria hegeliana, modos que passam pela relação entre a objetivação (Vergegenstandlichung), a alienação (Entäusserung) e o estranhamento (Entfremdung). Se alguns puderam dizer, passando por autores como Schleiermacher, Dilthey, Heidegger e Gadamer, que a hermenêutica se conforma também enquanto uma "teoria filosófica do conhecimento" (SCHIMDT, 2006, p. 11), inclusive permeada

29 Ricardo Salgado (2008, p. 88), com uma dicção kantiana, vem a expressar isto apontando que "historicidade, tradição e linguagem são, na verdade, a priori de toda e qualquer interpretação ou hermenêutica. História e linguagem são condições a priori de sensibilidade, pelas quais é a possível a experiência hermenêutica. A tradição e as formas representativas só podem ocorrer pela comunicação da linguagem e pela sucessão na história. Na história está embutida a condição a priori do tempo. O outro traz graças a sua exterioridade a condição de espaço uma vez que toda comunicação prescinde do outro para se realizar." 
por certa problemática que não deixa de render homenagem à tradição de exegese dos "textos sagrados" (Schleiermacher) ${ }^{30}$, isso se dá visto que não se tem tanto a totalidade da práxis humana - conformada na "atividade humana sensível" (sinnlich menchliche Tätigkeit) - como algo central, mas uma postura que, ao procurar se desvencilhar do idealismo especulativo hegeliano, vem a atribuir um papel central à compreensão e ao modo pelo qual ela vem a ser marcada por particularismos elimináveis de cada ser-aí (Dasein), "o ente (Seiende) dotado de um privilégio ôntico-ontológico" em Heidegger (2005b, p. 68).

Se a noção de realidade efetiva (Wirklichkeit) vem a ser central para a tradição hegeliana (e a marxista), o mesmo não se dá com Heidegger e Gadamer, os quais, em meio à tematização da "diferença ontológica" (ontologisch Differenz), apontam que uma abordagem que se atenha à centralidade da noção de realidade efetiva perder-se-ia também em meio à "metafísica", que ficaria adstrita, ao fim, a uma apreensão que não viria a questionar realmente o imediatismo do fenômeno. Segundo Heidegger (2005, p. 23), "a metafísica representa realmente o ente (Seiende) em seu ser (Sein) e pensa assim o ser do ente. Mas ela não pensa a diferença de ambos. A metafísica não levanta a questão do serele-mesmo." 31.

Assim, percebe-se que, diante de distintos modos de procurar resolver questões colocadas na filosofia hegeliana, a partir da

30 Segundo Schleiermacher (1999, p.67), inclusive, diz: "que eles são sagrados, sabe-se apenas na medida em que se os houver compreendido." Complementa depois dizendo que "seguramente não se pode compreender o espírito sagrado sem o espírito sagrado".

31 De certo modo, a questão já estava, com tons românticos, presentes no próprio Dilthey (1950, p.208), que não deixou de ver o contexto posterior à 1848 (ano em que o Manifesto comunista é publicado e em que se tem a primeira vez em que os trabalhadores aparecem em cena no nível europeu) como aquele em que, ao se tratar da positividade, ter-se-ia um rebaixamento da filosofia mesma: "a função da direção da vida, que cabia ao espírito filosófico, deslocou-se da vasta metafísica sistemática para o trabalho de investigação positiva. A partir de meados do século XIX, diversos fatores levaram a uma diminuição extraordinária da influência que a filosofia sistemática costumava exercer sobre as ciências, a literatura, a vida religiosa e a política. As lutas, desde 1848, para a libertação dos povos e formação dos estados nacionais na Alemanha e da Itália, o rápido desenvolvimento econômico e o defasamento que assim se produz quanto ao poder das classes e, finalmente, a política mundial, fizeram diminuir o interesse pela especulação abstrata." 
tematização das objetivações (Vergegenständlichung) humanas, tem-se a conformação da postura hermenêutica se configurando, até certo ponto, em oposição àquela marxiana, sendo a explicitação destas diferenças frutífera, tanto para a ontologia marxista quanto para a tradição, a qual, tendo em conta que "a fenomenologia é a via de acesso e o modo de verificação para se determinar o que deve constituir tema da ontologia. A ontologia só é possível como fenomenologia" (HEIDEGGER, 2005b, p. 66), opor-se-á de modo direto à posição (Standpunkt) segundo a qual a "disputa acerca da realidade ou não realidade de um pensamento que se isola da prática é uma questão puramente escolástica", e que, assim, coloca a "atividade humana sensível" (sinnlich menchliche Tätigkeit) como parâmetro da realidade (Wirklichkeit).

Em Heidegger e Gadamer, ater-se à "atividade humana sensível" seria o mesmo que se perder em meio ao ôntico, deixando de ter em conta algo essencial para a posição hermenêutica, a abertura (Erschlossenheit) frente ao que se apresenta de imediato. Dessa forma, a sombra de Hegel ainda paira no ar, tanto na tradição que conforma a hermenêutica filosófica quanto no marxismo. Logo, a tematização desta questão passa pelo modo como se concatenam categorias como objetivação (Vergegenstandlichung), alienação (Entäusserung), estranhamento (Entfremdung) e, de modos distintos, a venda (Veräusserung) em Marx, o distanciamento (Verfremdung) em Ricoeur, e a objetivação em Emílio Betti, todas, categorias que se relacionam ainda intimamente, mesmo que de modo mediado, com o universo categorial hegeliano. Assim sendo, é necessário, novamente, apontar o caráter proveitoso do embate a ser estabelecido, às claras, em torno de distintas posições (e oposições) quanto a Hegel.

\section{Heidegger, Marx, o estranhamento e a reificação}

A questão se torna ainda mais pungente quando se percebe que autores como Heidegger e Gadamer têm em conta explicitamente outros temas como a reificação (Verdinglichung), indissociável do modo eivado pelo estranhamento (Entfremdung) pelo qual as objetivações 
(Vergegenständlichung) se apresentam em meio ao desenvolvimento da moderna sociedade civil-burguesa (Burgerliche Gesellschaft). Heidegger, inclusive, vai dizer sobre a história algo essencial para o que se deseja tratar aqui e que pode dar margem, também por parte dos heideggerianos, gadamerianos e dos hermeneutas em geral, a um estudo mais sério sobre a filosofia de Marx. Diz o autor de Ser e tempo:

A apatricidade (Heimatlosigkeit) torna-se o destino do mundo (Welt). É por isso que se torna necessário pensar esse destino sob o ponto de vista ontológico-historial. O que Marx, a partir de Hegel, reconheceu, num sentido essencial e significativo, como alienação (Entfremdung) do homem, alcança, com suas raízes, até a apatricidade do homem moderno. Esta alienação é provocada e isto, a partir do destino do ser (Sein), na forma da Metafísica, é por ela consolidada e ao mesmo tempo por ela encoberta, como apatricidade. Pelo que Marx, enquanto experimenta a alienação, atingir uma dimensão essencial da história, a visão marxista da História é superior a qualquer outro tipo de historiografia. Mas porque nem Husserl, nem, quanto eu saiba até agora, Sartre reconhecem que a dimensão essencial do elemento da história reside no ser, por isso, nem a Fenomenologia, nem o Existencialismo atingem aquela dimensão, no qual é, em primeiro lugar, possível um diálogo produtivo com o marxismo. (HEIDEGGER, 2005, p. 48-49)

Heidegger explicitamente reconhece ser possível "um diálogo produtivo com o marxismo" e, neste sentido, percebe a presença da temática marxiana do estranhamento (Entfremdung) em seu próprio pensamento, e chega mesmo a colocar o modo pelo qual Marx trata da questão da história (Gechichte) como superior a todas as demais no campo da historiografia (Historie). Isto é, o autor reconhece um grande mérito no autor de O capital (ele "experimenta o estranhamento (Entfremdung)" efetivamente), o que dá suporte àquilo que estamos procurando explicitar neste texto: a necessidade de um embate cuidadoso entre a tradição hermenêutica e a marxista (sobretudo tendo em mente autores como, de um lado, György Lukács, e, por outro, 
Ricoeur). No entanto, ao mesmo tempo, Heidegger coloca a posição marxista como algo ligado ao aspecto ôntico somente, sendo incapaz de remeter à questão do Ser (Sein).

Nesse ponto, Marx permaneceria no plano de uma historiografia, em Heidegger, destituída de um aspecto ontológico, tratado em Ser e tempo com referência a uma "ontologia fundamental". Nesse sentido, parece que há certo cuidado por parte de Heidegger ao tratar do estranhamento, inclusive com referência ao trabalho de Marx (SARTORI, 2010), e, dessa forma, a presença de um embate é explícito. No entanto, ao mesmo tempo, uma análise dos textos do próprio Marx é absolutamente ausente na obra heideggeriana. Além disso, temáticas como aquelas relacionadas à vida cotidiana (Alltagsleben) estão claramente presentes tanto em Heidegger como em marxistas, tais como Kosik, Lukács e Benjamin, para não dizer, mesmo que de modo mediado, no próprio Marx. Todo isso ocorre na medida em que esses autores não são estudados na tradição da hermenêutica filosófica nem mesmo como contrapontos "exóticos".

Heidegger ainda traz à tona a temática da objetivação (Vergegenstandlichung), ligando-a, inclusive, àreificação(Verdinglichung) (SARTORI, 2010, 2012), de tal feita que procura um modo de lidar com o mundo que não seja, em verdade, marcado pela objetivação, pois, para o autor, "a experiência cotidiana das coisas em sentido amplo nem é objetivante nem é objetivação." (HEIDEGGER, 2008b, p. 83) ) $^{32}$. Neste sentido, ao lidar com um mundo eivado pela reificação e com um

32 O autor trata da questão, inclusive, remetendo à questão estética, o que resta claro em $A$ origem da obra de arte, mas também na continuação da passagem citada acima: "quando, por exemplo, sentados no jardim, alegramo-nos com as rodas da flor, não fazemos da rosa um objeto e nem mesmo alguma coisa que se encontra contraposta, ou seja, algo tematicamente representado. Quando em dizer silencioso, entrego-me ao vermelho brilhante da rosa e medito sobre o servermelho da rosa, esse ser-vermelho não é objeto nem é coisa e nem algo que se contrapõe como a rosa em flor. A rosa está no jardim, balança para lá e para cá ao sabor do vento. Já o ser-vermelho da rosa não está no jardim e nem pode balançar ao sabor do vento. Todavia, penso e falo do ser-vermelho quando o nomeio. Assim, realiza-se um pensar e um dizer que, de modo algum, produz uma objetivação. (HEIDEGGER, 2008b, p. 83) Para uma análise mais cuidadosa da passagem. (SARTORI, 2012). 
cotidiano estranhado ${ }^{33}$, a solução de Heidegger, até certo ponto, não passa tão longe daquela criticada por Marx em Hegel: "a suprassunção (Aufhebung) do estranhamento (Entfremdung) é identificado com a suprassunção da objetividade (Gegenständlichkeit)." A realidade efetiva (Wirklichkeit) mesma, desde o autor da Fenomenologia do espírito, é marcada por uma indissociabilidade entre subjetividade e objetividade, interioridade e exterioridade (para Hegel, "a efetividade (Wirklichkeit) é a unidade, que veio a ser imediatamente, da essência e da existência, ou do interior e do exterior." (HEGEL, 2005, p. 266). Assim, novamente, para a tradição hermenêutica, haveria "dialética" em demasia. Portanto, não se trataria tanto de buscar uma apreensão mais cuidadosa da realidade efetiva mesma, mas de, por meio do percurso de abertura que se dá tendo em conta a linguagem e o privilégio "ôntico-ontológico" do ser-aí (Dasein), remeter para o Ser (Sein), que seria essencialmente um transcendens sendo a questão da verdade, em si, algo ligado ao desvelamento que remetesse para além da objetividade mesma. ${ }^{34}$

33 Neste ponto, vale fazer referência à famosa passagem de Ser e tempo, em que Heidegger trata da cotidianidade (Alltaglichkeit) da seguinte maneira: "na utilização dos meios de transporte público, no emprego de meios de comunicação e notícias (jornal), cada um é com o outro. Este conviver dissolve inteiramente a própria pré-sença (Dasein) no modo de ser dos "outros" e isso de tal maneira que os outros desapareçam ainda mais em sua possibilidade de diferença e expressão. O impessoal (das Man) desenvolve sua própria ditadura nessa falta de surpresa e de possibilidade de constatação. Assim, nos divertimos e nos entretemos como impessoalmente se vê e julga; também nos retiramos das 'grandes multidões' como impessoalmente se retira; achamos 'revoltante' o que impessoalmente se considera revoltante. O impessoal que não é nada determinado mas que todos são, embora não como soma, prescreve o modo de ser da cotidianidade (Alltaglichkeit)." (HEIDEGGER, 2005, p. 179)

34 Como aponta Heidegger: "enquanto o tema fundamental da filosofia, o ser (Sein) não é o gênero dos entes (Seiende) e, não obstante, diz respeito a todo e qualquer ente. Sua 'universalidade' deve ser procurada ainda mais acima. O ser e a sua estrutura ontológica se acham acima de qualquer ente e de toda determinação ôntica possível de um ente. O ser é o transcendens pura e simplesmente. A transcendência do ser da pre-sença (Dasein) é privilegiada porque nela reside a possibilidade (Möglichkeit) e a necessidade da individuação mais radical. Toda e qualquer abertura (Erschlossenheit) do ser enquanto transcendens é conhecimento transcendental. A verdade fenomenológica (abertura do ser) é veritas transcendentalis." (HEIDEGGER, 2005, p. 69) 


\section{Gadamer e a hermenêutica filosófica à luz da "ausência- presença" de Marx}

Por fim, vale a pena analisar, mesmo que de modo bastante sumário, algumas questões que, de certo modo, já estavam presentes em Dilthey e Heidegger em meio à tematização da historicidade (Gechichlichkeit) (e da vida (Leben)) e da cotidianidade (Alltaglichkeit), mas que aparecem com força em Gadamer visto que justamente a historicidade marca a compreensão (Verstehen) do modo que tradição e efetividade (Wirklichkeit) somente poderiam ser tratadas em conjunto. Isso se daria, inclusive, porque a compreensão mesma traria consigo pré-compreensões, no limite, conformadas enquanto prejuízo, preconceito (Vorurteil), condições históricas constitutivas do horizonte do ser-aí (Dasein) e que, assim, não poderiam simplesmente ser ignoradas em nome de uma pretensa atitude "objetiva" ${ }^{35}$, tratandose, antes, de enxergar a compreensão como algo indissociável do próprio acontecimento (Ereignis) constitutivo do sentido (Sinn), pois "a compreensão deve ser entendida como parte do acontecimento semântico, no qual se forma e se realiza o sentido de todo o enunciado, tanto os enunciados da arte quanto os de qualquer outra tradição" (GADAMER, 1997, p. 231). Gadamer procura um modo de interpelação que traga consigo a possibilidade de, ao mesmo tempo, não deixar de destacar o papel decisivo das pré-compreensões na conformação do ser-aí em sua historicidade (Gechichlichkeit) e não se deixar dominar simplesmente por ela. Assim, tratar-se-ia de "distinguir os verdadeiros preconceitos, sob os quais compreendemos dos falsos preconceitos que produzem mal-entendidos." (GADAMER, 1997, p. 395). Diz o autor:

O primeiro elemento com que se inicia a compressão (Verstehen) é o fato de que algo nos interpela. É a primeira

35 Segundo Gadamer (1997, p.358): "uma consciência formada hermeneuticamente deve, desde o princípio, mostrar-se receptiva à alteridade do texto. Mas esta receptividade não pressupõe nem uma 'neutralidade' com relação à coisa, nem tampouco um anulamento de si mesma; implica antes uma destacada apropriação das opiniões prévias e preconceitos pessoais. O que importa é dar-se conta dos próprios pressupostos, a fim de que o próprio texto possa apresentar-se em sua alteridade, podendo, assim, conformar sua verdade com as opiniões prévias pessoais." 
de todas as condições hermenêuticas. Agora vemos o que se exige para isso: uma suspensão fundamental dos próprios preconceitos. Toda suspensão de juízos, porém, começando pelos preconceitos, logicamente falando, possui a estrutura de pergunta. [...] A essência da pergunta é colocar possibilidades e mantê-las em aberto. (GADAMER 2002, p. 81)

Neste sentido, a atividade hermenêutica traria consigo uma forma dupla de apropriação: num primeiro momento, a apropriação daquilo que aparece somente enquanto um "pré" e que, ao ser trazido à tona na interpretação em relação com a tradição ${ }^{36}$, poderia passar por uma "suspensão fundamental". Em um segundo momento, tem-se a apropriação daquilo colocado enquanto algo de estranhado na própria "coisa" a ser interpretada. Para Gadamer, "o que importa é dar-se conta dos próprios pressupostos, a fim de que o próprio texto possa apresentarse em sua alteridade, podendo, assim, conformar sua verdade com as opiniões prévias pessoais". Logo, a passagem entre passado e presente, característica da tematização da historicidade (Gechichlichkeit), traz consigo a constituição da existência humana marcada por aquilo que, no nível da vida (Leben), nos é legado pelo passado e que, até certo ponto, assombra-nos, colocando em risco - ao mesmo tempo em que tem que ser assumido - a compreensão (Vertehen), para o autor de Verdade e método, digna de tal nome.

É importante destacar que, nesse ponto, que traz consigo a problemática, talvez, mais pungente na tradição da hermenêutica filosófica, também não deixa de existir contato com Marx, como reconheceu alguém tão distante do marxismo e mais próximo da tradição que tratamos: Derrida (1994). A questão se apresenta na medida em que, segundo Marx, não é pelo fato do homem, ao final, "fazer sua própria história", que esta não se contrapõe a ele, na sociedade civilburguesa (burguerliche Gesellschaft), enquanto uma potência (Macht)

\footnotetext{
36 Seria necessário justamente o "encontro com a tradição, pois o que incita o compreender deve ser feito valer já, de algum modo, em sua própria alteridade." (GADAMER, 2002, p. 81)
} 
eivada pelo estranhamento (Entfremdung). Em verdade, o homem, por meio da atividade humana sensível (sinnlich menchliche Tätigkeit) traz objetivações (Vergegenständlichung) que, mediante um contexto social e histórico, apresentam-se à medida que há, objetivamente, "a 'sociedade' como abstração frente o indivíduo." (MARX, 2004, p. 107)

Dito de outra forma, a própria vida (Leben) do indivíduo aparece marcada por uma força estranhada que pode mesmo aparecer, ideológica e cotidianamente, como "a Sociedade" e, nesse sentido específico, tanto há uma tematização explícita em Marx sobre a exteriorização da vida (Lebensäusserung) nos Manuscritos econômico-filosóficos (tendose por óbvio que a vida mesma não é dissolvida em qualquer espécie de lógica ou de modelo) quanto mediações sociais que permeiam a vida cotidiana (Alltagsleben) do homem na sociedade civil-burguesa o levariam a uma situação em que a objetivação vem a ser marcada pelo estranhamento. Tendo em conta toda a problemática acima, é preciso expor que, após tudo isso, não é possível dizer que tal aspecto "social" em Marx iguala-se a qualquer "sociologismo vulgar". Trata-se de questões sociais e ligadas à práxis, em que esta última, longe de trazer uma compreensão escolar, problematiza, ao mesmo tempo, as vicissitudes da sociedade em que vivemos e aquilo que é trazido com o melhor da filosofia não marxista.

Nesta situação, concreta e inseparável da compreensão real e efetiva da atividade sensível (sinnlich menchliche Tätigkeit), diz Marx que os homens fazem sua própria história na medida em que "a tradição de todas as gerações mortas oprime como um pesadelo o cérebro dos vivos." (MARX, 1997, p. 21). Portanto, parece ser bastante importante o estabelecimento de um embate sério entre duas tradições que advêm da crítica ao hegelianismo e que trazem à tona categorias bastante presentes na filosofia hegeliana, tais como aquelas de objetivação (Vergegenstandlichung), alienação (Entäusserung) e estranhamento (Enfremdung).

Em grande parte, a hermenêutica filosófica está marcada por um desconhecimento daquilo que há de mais proveitoso na filosofia 
marxiana. Por vezes, inclusive, deixando de considerar o corpus da obra de Marx enquanto algo digno de respeito. ${ }^{37}$ Dessa maneira, sua solução às aporias da filosofia hegeliana teriam se dado de modo oposto: de um lado, tendo-se em conta os meandros da compreensão (Verstehen), depois de um momento em que parecia não ser mais possível voltar a uma epistemologia de base kantiana, sendo necessário remeter à vida (Leben); e, de outro lado, tendo em conta a tematização da própria atividade humana sensível, que parece ter sido renegada a um segundo plano. Isso ocorreria, por sua vez, na medida em que se teria um grande perigo, que foi destacado por György Lukács (2010), no século XX, em relação àquilo que chamou de decadência ideológica: poder-se-ia, assim, haver um desprezo à história à medida que a experiência vivida estaria sendo valorizada e, segundo o autor, "paralelamente a este desprezo pelos fatos históricos, pelas forças reais motrizes da história, surge uma tendência à mistificação." (LUKÁCS, 2010, p. 53). Assim, também para que tente se esquivar deste risco, a hermenêutica filosófica poderia ter em conta, com mais cuidado, a obra de Marx.

\section{Conclusão}

Percebe-se, portanto, que, se há uma peculiar "ausênciapresença" do pensamento marxiano na hermenêutica filosófica - que remete à hermenêutica jurídica compreendida em seu sentido mais amplo -, nada seria mais justo que um embate franco entre o marxismo e

37 Dilthey (1950, p. 209) dirá que, desde Hegel, e especialmente em Marx, ocorreu o que criticou: a subsunção da filosofia às ciências da natureza (Naturwissenschaft): "a economia política socialista funde-se com o pensamento científico natural, conquanto se encontre determinada por Hegel, Marx e Engels." Pelo que aqui expomos, claro, não concordamos com a posição de Dilthey, que tente a ver Marx como alguém marcado por uma posição (Standpunkt) eivada por uma apreensão reificada da realidade efetiva (Wirklichkeit), apreensão esta que, em verdade, mediante a tematização do estranhamento (Entfremdung), vê na economia política, a qual critica: Dilthey erra redondamente quanto à Marx na medida em que "os economistas burgueses estão tão encerrados nas representações de um determinado nível de desenvolvimento histórico da sociedade que a necessidade da objetivação (Vergegenstandlichung) das forças sociais do trabalho aparece-lhes inseparável da necessidade do estranhamento (Entfremdung) dessas forças frente o trabalho vivo." (MARX, 2011, p. 706) 
esta tradição. Os temas trazidos acima neste pequeno artigo (a relação homem-natureza, questão da efetividade, do estranhamento, dentre outras correlatas as quais, no limite, remetem à compreensão da própria atividade humana em sua complexidade real e efetiva) pretenderam traçar possíveis caminhos neste embate o qual, acreditamos, é bastante necessário. Dilthey, Heidegger, Gadamer e Ricouer, por exemplo, podem ser bem compreendidos tendo em conta este cenário, em que os posicionamentos quanto à filosofia hegeliana são centrais na conformação de distintas - mas correlacionadas - tradições filosóficas. Estes autores também precisam ser enxergados com um cuidado especial. Isto se dá porque uma análise cuidadosa da obra de Marx, pretendeu-se mostrar acima, é bastante necessária àqueles que pretendem levar a sério a empreitada crítica e filosófica. Se marxistas como Lukács - e, hoje, Nicolas Tertulian - estudam com cuidado aqueles que são seus antagonistas no plano filosófico, o mesmo deveria se das no terreno daqueles que partem da tradição da hermenêutica filosófica. Somente assim um embate franco, honesto e decidido é possível.

\section{Referências}

ABBIERO, Marcella. A "alienação" em Hegel: usos e significados de Entäusserung, Entfremdung, Veräusserung. Tradução por Ronaldo Vielmi Fortes. Verinotio - Revista online de filosofia e ciências humanas, Belo Horizonte, n. 19, p. 19-31, 2015.

ALVES, Antonio José Lopes. A questão do Standpunkt na cientificidade marxiana: a querela do trabalho produtivo na economia política.

Verinotio - Revista On Line de Educação e Ciências Humanas, Belo Horizonte, n. 12, p. 86-93, 2010.

BETTI, Emilio. Interpretação da lei e dos atos jurídicos. Tradução por Karina Janini. São Paulo: Martins Fontes, 2007.

CORREAS, Óscar. Crítica da ideologia jurídica: ensaio sóciosemiológico. Tradução por Roberto Bueno. Porto Alegre: Sergio Fabris, 1995. 
DERRIDA, Jacques. Espectros de Marx: o estado da dívida, o trabalho do luto e a nova internacional. Tradução por Anamaria Skinner. Rio de Janeiro: Relume-Dumará, 1994.

DILTHEY, Wilhelm. História da filosofia. Tradução de Silveira Mello. São Paulo: Livraria exposição do livro, 1950.

GADAMER, Hans-Georg. Hermenêutica em retrospectiva. Tradução por Marco Antônio Casanova. Petrópolis: Vozes, 2009.

. Verdade e método I. Tradução por Paulo Flávio Maier. Petrópolis: Vozes, 1997.

Verdade e método II. Tradução por Enio Paulo Giachini. Petrópolis: Vozes, 2002.

GRODIN, Jean. Introdução à hermenêutica filosófica. Tradução por Benno Dischinger. São Leopoldo, Unisinos, 1998.

HEGEL, Georg. Fenomenologia do espírito (Parte II). Tradução por Padre Henrique Lima Vaz. Petrópolis: Vozes, 1992.

. Enciclopédia das ciências filosóficas. Tradução por Paulo Menezes. São Paulo: Loylola, 2005. (A ciência da lógica, v. I).

HEIDEGGER, Martin. A origem da obra de arte. Tradução por Manuel Antonio Castro e Idalina Azevedo da Silva. Lisboa: Edições 70, 2010.

Ensaios e conferências. Tradução por Emanuel Carneiro Leão. Petrópolis: Vozes, 2008.

. Marcas do caminho. Tradução por Ernildo Stein. Petrópolis: Vozes, 2008b.

. O princípio do fundamento. Tradução por Jorge Telles Menezes. Lisboa: Instituto Piaget, 2000.

Ser e tempo. Tradução por Márcia de Sá Cavalcanti. Petrópolis: Vozes, 2005a. v. 1.

. Ser e tempo. Tradução por Márcia de Sá Cavalcanti. Petrópolis: Vozes, 2005b. v. 2. 
Ser y tempo. Tradução por José Gaos. México: Fondo de cultura, 2010.

KOSIK, Karel. Dialética do concreto. Tradução por Célia Neves e Alderico Toríbio. Rio de Janeiro: Paz e Terra, 1995.

LÉVINAS, Emmanuel. Descobrindo a existência com Husserl e Heidegger. Tradução por Fernanda Oliveira. Lisboa: Piaget, 1998.

LUKÁCS, György. Conversation with Gyorgy Lukács (Interview with Franco Ferrarotti). World View, New York, may, 1972. p. 30-34.

. Der Spigel entrevista o filósofo Lukács. Tradução de Rainer Patriota. Verinotio: Revista On Line de Educação e Ciências Humanas, Belo Horizonte, n. 9, p. 333-350, 2008 b.

. Diálogo sobre o Pensamento Vivido. In: Ensaio 15-16. Tradução por Equipe Ensaio. Ensaio, São Paulo, n. 15-16, p. 13-89, 1986.

. Estética, la peculiaridad de lo estético. Tradução por Manuel Sacristan. México: Ediciones Grijalbo, 1966. (Questiones Preliminares y de Princípio, v. 1)

. História e consciência de classe. Tradução por Rodnei Nascimento. São Paulo: Martins Fontes, 2003.

. Marxismo e teoria da literatura. Tradução por Carlos Nelson Coutinho. São Paulo: Expressão Popular, 2010b.

. Prolegômenos para uma ontologia do ser social. Tradução por Lya Luft e Rodnei Nascimento. São Paulo: Boitempo, 2010.

. Ontologia do ser social I. Tradução por Carlos Nelson Coutinho, Mario Duayer e Nélio Schneider. São Paulo: Boitempo, 2012.

. Ontologia do ser social II. Tradução por Nélio Schneider. São Paulo: Boitempo, 2013.

. The Twin crisis. In: New Left Review I/60. London, 1970. 
MARX, Karl. Crítica da filosofia do direito de Hegel. Tradução de Rubens Enderle e Leonardo de Deus. São Paulo: Boitempo, 2005.

. Das Kapital I. In: MARX, Karl; ENGELS, Friedrich. Band 23. Berlin: Dietz Verlag, 1968. 11-802.

. Grundrisse. Tradução de Martin Nicolaus. London: Penguin Books, 1993.

. Grundrisse. Tradução por Mario Duayer. São Paulo:

Boitempo, 2011.

O 18 Brumário de Luiz Bonaparte. Tradução de Leandro Konder e Renato Guimarães. Rio de Janeiro: Paz e Terra, 1997.

Manuscritos econômico-filosóficos. Tradução de Jesus Ranieri. São Paulo: Boitempo, 2004.

. O capital. Tradução por Rubens Enderle. São Paulo:

Boitempo, 2013.

. Ökonnomich-philosophische Manuskripte. In: MEGA 1, 2. Berlin: Dietz Verlag, 1982.

Zur Kritik der Hegelschen Rechtsphilosophie. In: Marx/ Engels Werke. Band 1. Berlin: Dietz, 1981.

MARX, Karl; ENGELS, Friedrich. Ideologia alemã. Tradução por Rubens Enderle. São Paulo: Boitempo, 2007.

. Teses ad Feuerbach. In: MARX, Karl; ENGELS, Friedrich. A ideologia alemã. Tradução por Rubens Enderle. São Paulo: Boitempo, 2007.

. Thesen über Feuerbach. In: MEGA 1, 2. Berlin: Dietz Verlag, 1979.

RANIERI, Jesus. Trabalho e dialética: Hegel, Marx e a teoria social do devir. São Paulo, Boitempo, 2011.

RICOEUR, Paul. Hermenêutica e ideologias. Tradução por Milton Japiassu. Petrópolis: Vozes, 2008. 
. Teoria da interpretação. Tradução por Artur Morão. Lisboa: Edições 70, 2009.

SARTORI, Vitor Bartoletti. De Hegel a Marx: da inflexão ontológica à antítese direta. Kriterion: Revista de Filosofia, Belo Horizonte, v. 55, n.130, p. 691-713, 2014.

. Lukács e a questão da técnica em Heidegger. Verinotio:

Revista On Line de Educação e Ciências Humanas, Belo Horizonte, n. 13, p. 68-89, 2012.

. O segundo Heidegger e Lukács: alienação, história e práxis. Verinotio: Revista On Line de Educação e Ciências Humanas, Belo Horizonte, n. 11, p. 23-44, 2010.

SALGADO, Ricardo Henrique Carvalho. A fundamentação da ciência da hermenêutica em Kant. Belo Horizonte: Diálogo, 2008.

SCHLEIERMACHER, Friedrich D.E. Hermenêutica: arte e técnica da interpretação. Tradução por Celso Reni Braida. Petrópolis:Vozes, 1999.

SCHMIDT, Lawrance K. Hermenêutica. Tradução por Fábio Ribeiro. Petrópolis: Vozes, 2006.

TERTULIAN, Nicolas. Aliénation et desaliénation: une confrontation Lukács-Heidegger. Actuel Marx, Paris, n. 39, p. 29-53, 2006.

. L'Ontologie chez Heidegger et Lukács: 'phenoménologie et dialetic. Kriterion: Revista de Filosofia, Belo Horizonte, v. 50, n. 119, p. 23-41, 2009.

Recebido em: 09/09/2015

Aprovado em: 13/10/2015 